\title{
SCREENING FOR LIGNINOLYTIC ENZYMES FROM AUTOCHTHONOUS FUNGI AND APPLICATIONS FOR DECOLORIZATION OF REMAZOLE MARINE BLUE
}

\author{
Emre Erden ${ }^{1}$; M. Cigdem Ucar'; TekinGezer²; Nurdan Kasikara Pazarlioglu ${ }^{1 *}$ \\ ${ }^{1}$ Ege University, Faculty of Science, Biochemistry Department, 35100 Bornova, Izmir, TURKIYE; \\ ${ }^{2}$ Biology Dept. Microbiology Section 35100 Bornova, Izmir, TURKIYE
}

Submitted: April 11, 2008; Returned to authors for corrections: August 27, 2008; Approved: February 15, 2009.

\begin{abstract}
This study presents new and alternative fungal strains for the production of ligninolytic enzymes which have great potential to use in industrial and biotechnological processes. Thirty autochthonous fungal strains were harvested from Bornova-Izmir in Turkiye. In the fresh fruitbody extracts laccase, manganese peroxidase and lignin peroxidase activities, which are the principal enzymes responsible for ligninocellulose degradation by Basidiomycetes, were screened. Spores of some of the basidiomycetes species such as Cortinarius sp., Trametes versicolor, Pleurotus ostreatus, Abortiporus biennis, Lyophyllum subglobisporium, Ramaria stricta, Ganoderma carnosum, Lactarius delicious ve Lepista nuda were isolated and investigated optimum cultivation conditions in submerged fermentation for high yields of ligninolytic enzyme production. In addition, isolated fungal strains were monitored on agar plates whether having the capability of decolorization of a textile dye Remazol Marine Blue.
\end{abstract}

Key words: Basidiomycetes, ligninolytic enzymes, decolorization

\section{INTRODUCTION}

Basidiomycetes constitute the most conspicuous group of fungi in the environment and comprise very different ecological groups such as white rot, brown rot, and leaf litter fungi. Some of them are edible and/or medicinal fungi; some have important biotechnological and environmental applications (31).

White-rot fungi, belonging to the basidiomycetes, are the only organisms capable of mineralizing lignin efficiently. Lignin, which is one of the most widely distributed natural organic polymers, is very slowly decomposed in the environment due to its complex chemical structure. Lignin biodegradation performed by these fungi is a multistep process mediated by enzymes of the lignolytic complex. The rate of lignin decomposition depends on the concentration of molecular oxygen. Both the nature and direction of this process can be different in different fungi (27). The most efficient lignin degraders were estimated by ${ }^{14} \mathrm{CO}_{2}$ evolution from ${ }^{14} \mathrm{C}$-[Ring]-labelled synthetic lignin (DHP) $(13,35)$. In order to depolymerize and mineralize lignin, they have developed an oxidative and unspecific system including extracellular enzymes, low molecular weight metabolites and activated oxygen species $(28,29)$. The extracellular enzymatic systems include laccase (benzendiol: oxygen oxidoreductase) (Lac, EC 1.10.3.2.), manganese peroxidase (MnP, EC 1.11.1.13) and lignin peroxidase (LiP, EC 1.11.1.14). Manganese peroxidase is a heme glycoprotein that catalyzes the oxidation of $\mathrm{Mn}^{2+}$ to $\mathrm{Mn}^{3+}$ in the presence of $\mathrm{H}_{2} \mathrm{O}_{2} . \mathrm{Mn}^{3+}$ is efficiently stabilized in aqueous solution by $\alpha-$ hydroxy acids (11). These complexes function as diffusible oxidants that can oxidize terminal phenolic substrates and also possibly nonphenolic substitutents via a radical mediator (3). Lignin peroxidase $(\mathrm{LiP})$ plays a central role in the biodegradation of the plant cell wall constituent lignin. LiP is able to oxidize aromatic compounds with redox potentials higher than $1.4 \mathrm{~V}$ (NHE) by single electron abstraction, but the exact redox mechanism is still poorly understood (25). Laccases are glycoprotein belonging to the blue multicopper oxidases and they are able to oxidize phenols and aromatic amines with reducing molecular oxygen to water (5). The physiological roles of fungal

*Corresponding Author. Mailing address: Ege University, Faculty of Science, Biochemistry Department, 35100 Bornova, Izmir, TURKIYE. Tel.: + 9023238840 00/ 2396. Fax: + 9023234386 24. E-mail: nurdan.pazarlioglu@ege.edu.tr 
laccases include pigment production, plant pathogens and as well as degradation of lignocellulosic materials (33).

Ligninolytic enzymes have a potential in several industrial and biotechnological processes within a wide variety of organic and inorganic substrate specificities (6). Such applications include the detoxification of industrial effluent $(23,36)$, mostly from, textile and petrochemical industries, bleaching and delignification processes in the paper and pulp industries (1), removing the phenolic compounds from the beer and wine in the food industry (21). In addition, their capacity to remove xenobiotic substances and produce polymeric products makes them a useful tool for bioremediation purposes (26).

In recent years, there has been a growing interest in screening researches for new and alternative fungal strains for producing of value-added and efficient ligninolytic enzymes. Several screening works about ligninolytic enzymes have been carried out mainly in white-rot basidiomycetes (9). In these studies fungal strains were searched for detecting the ability to produce lignin-modifying enzymes $(9,28)$. This study presents an initial screening method for detecting ligninolytic enzymes in a little while and suggests an estimation whether fungal strain will secrete these enzymes or not. For this purpose, fruiting bodies were used to investigate ligninolytic activities as first time and fungal isolates were used to determine the ligninolytic activity with a conventional method. Cultivation conditions in submerged fermentation for high yields of enzyme production by isolated fungi were optimized. Additionally, dye decolorization ability of produced enzymes was tested.

\section{MATERIALS AND METHODS}

\section{Screening for ligninolytic enzyme production in fresh fruit bodies}

Thirty fungal strains were harvested from different habitats around Bornova - Izmir in Turkiye. Amount of fresh fruit bodies were cut into the pieces and transferred to the polystyrene tubes with adding acceptable proportion of phosphate buffer, $\mathrm{pH}$ 6.0. They were homogenized for 3 minutes at $+4^{\circ} \mathrm{C}$ with homogenizer (IKA T10 Basic Ultra-Turrax, 220-240 volt, 50/60 $\mathrm{Hz}$ ) and for 5 minutes at $+4^{\circ} \mathrm{C}$ with sonicator (Sonics Vibracell VCX $130 \mathrm{~PB}, 130$ watt, $20 \mathrm{KHz}$ ). Homogenates were centrifuged at $+4^{\circ} \mathrm{C}$ in $10.000 \mathrm{rpm}$ for $25 \mathrm{~min}$ (HETTICH UNIVERSAL 30 RF) and then the ligninolytic enzyme activities were determined in supernatants.

\section{Isolation of fungal strains and secondary screening on solid medium with isolated fungi}

Malt extract agar (MEA) (Merck), potato dextrose agar (PDA) (Fluka) and yeast extract agar (YEA) were used to isolate fungi. Recent years, the traditional screening reagents tannic and gallic acid have been replaced with synthetic phenolic reagents such as guaiacol and syringaldazine and the production of ligninolytic enzymes is observed as a colorless halo around microbial growth $(7,16,24)$. Therefore, $0.01 \%$ guaiacol and syringaldazine were added to the solid medium and incubated at $26^{\circ} \mathrm{C}$. With guaiacol positive reaction was indicated by the formation of a reddishbrown halo.

\section{Culture conditions for ligninolytic enzyme production}

Isolated fungal strains were maintained on $2 \%(\mathrm{w} / \mathrm{v})$ MEA or PDA slants at $4^{\circ} \mathrm{C}$ and the fungi were activated at $26^{\circ} \mathrm{C}$. The mycelium were harvested with sterile $0.9 \% \mathrm{NaCl}$ solution and then inoculated into $100 \mathrm{ml} 2 \%$ malt extract broth or potato dextrose broth in $250 \mathrm{ml}$ Erlenmeyer flasks at $26^{\circ} \mathrm{C}$ and $165 \mathrm{rpm}$. Cultivation was carried out in an orbital shaker. In both stages, incubation time depends on the fungal strains. After the growth period, pellets were inoculated $250 \mathrm{ml}$ Erlenmeyer flasks containing medium and incubated at $26^{\circ} \mathrm{C}$ and $165 \mathrm{rpm}$. In order to optimize enzyme production, different media and agitation rates $(90,130$ and $165 \mathrm{rpm})$ were used. The media were composed of:

M1: $10 \mathrm{~g} / 1$ glucose, $0.025 \mathrm{~g} / 1$ yeast extract, $0.05 \mathrm{~g} / \mathrm{l}$ $\mathrm{MgSO}_{4} .7 \mathrm{H}_{2} \mathrm{O}, 1.0 \mathrm{~g} / 1 \mathrm{NH}_{4} \mathrm{H}_{2} \mathrm{PO}_{4}$ and adjusted at $\mathrm{pH} 4.5$.

$\mathrm{M} 2: 10 \mathrm{~g} / \mathrm{l}$ glucose, $5.0 \mathrm{~g} / \mathrm{l}$ yeast extract, $0.22 \mathrm{~g} / \mathrm{l}$ ammonium tartarate, $2 \mathrm{~g} / 1 \mathrm{KH}_{2} \mathrm{PO}_{4}, 0.05 \mathrm{~g} / \mathrm{l} \mathrm{MgSO}{ }_{4} .7 \mathrm{H}_{2} \mathrm{O}, 0.1 \mathrm{~g} / \mathrm{CaCl}_{2} .2 \mathrm{H}_{2} \mathrm{O}$, $0.5 \mathrm{~g} / \mathrm{l} \mathrm{KCl}, 0.2 \mathrm{~g} / \mathrm{l}$ Thiamin, $10 \mathrm{ml} / \mathrm{l}$ trace element solution and adjusted at $\mathrm{pH} 4.5$.

M3: $10 \mathrm{~g} / 1$ glucose, $0.22 \mathrm{~g} / \mathrm{l}$ ammonium tartarate, $0.2 \mathrm{~g} / \mathrm{l}$ $\mathrm{KH}_{2} \mathrm{PO}_{4}, 0.05 \mathrm{~g} / 1 \mathrm{MgSO}_{4} .7 \mathrm{H}_{2} \mathrm{O}, 0.01 \mathrm{~g} / \mathrm{CaCl}_{2} .2 \mathrm{H}_{2} \mathrm{O}, 0.001 \mathrm{~g} / \mathrm{l}$ Thiamin, $10 \mathrm{ml} / \mathrm{l}$ trace element solution, $10 \mathrm{ml} / \mathrm{l} 10 \%$ Tween solution, $1.5 \mathrm{mM}$ veratryl alcohol (VA) and adjusted at $\mathrm{pH} 4.5$.

Trace element solution was composed of $1.0 \mathrm{~g} / 1 \mathrm{FeSO}_{4} \cdot 7 \mathrm{H}_{2} \mathrm{O}$, $1.0 \mathrm{~g} / \mathrm{MnSO}_{4} \cdot \mathrm{H}_{2} \mathrm{O}, 0.25 \mathrm{~g} / 1 \mathrm{NaMoO} \cdot 2 \mathrm{H}_{2} \mathrm{O}, 0.10 \mathrm{~g} / \mathrm{H}_{3} \mathrm{BO}_{3}, 0.25$ $\mathrm{g} / \mathrm{lCuSO}_{4} .7 \mathrm{H}_{2} \mathrm{O}, 0.25 \mathrm{~g} / \mathrm{ZnSO}_{4} .7 \mathrm{H}_{2} \mathrm{O}, 0.10 \mathrm{~g} / \mathrm{l} \mathrm{NH}_{4} \mathrm{NO}_{3}, 0.50 \mathrm{~g} / \mathrm{l}$ $\mathrm{C}_{\mathrm{O}}\left(\mathrm{NO}_{3}\right)_{2} \cdot 6 \mathrm{H}_{2} \mathrm{O}, 0.01 \mathrm{~g} / 1 \mathrm{NiSO}_{4} \cdot 6 \mathrm{H}_{2} \mathrm{O}$ and $5 \mathrm{ml} / 1 \mathrm{H}_{2} \mathrm{SO}_{4}(95-98 \%)$.

Each sample was centrifuged at $10.000 \mathrm{rpm}$ for $15 \mathrm{~min}$ and supernatant of the culture was used for enzymatic assays. All enzymatic analysis was carried out in duplicated.

\section{Enzyme assays}

Laccase (Lac) activity was assessed by measurement of enzymatic oxidation of 2,2 -azinobis-(3-ethylbenzothiazoline- 6sulphonic acid) (ABTS) at $420 \mathrm{~nm}\left(\varepsilon=3,6.10^{4} \mathrm{~cm}^{-1} \mathrm{M}^{-1}\right)$.One Unit of enzyme activity is defined as the amount of enzyme that oxidizes $1 \mathrm{mmol}$ ABTS in $1 \mathrm{~min}$ (4).

Mn peroxidase (MnP) (EC 1.11.1.13) activity was measured by monitoring the increase in absorbance at $469 \mathrm{~nm}$ due to the oxidation of 2,6-dimethoxyphenol (DMP) at the present of $\mathrm{H}_{2} \mathrm{O}_{2}\left(\varepsilon=4.9610^{4} \mathrm{~cm}^{-1} \mathrm{M}^{-1}\right)$ and $\mathrm{MnSO}_{4}$. One activity unit was defined as the amount of enzyme that oxidized $1 \mathrm{mmol}$ of DMP per minute (18).

Lignin peroxidase activity was determined by $\mathrm{H}_{2} \mathrm{O}_{2}$ dependent veratraldehyde formation from veratryl alcohol at $310 \mathrm{~nm}\left(\varepsilon_{310}=\right.$ $9.3 \mathrm{~cm}^{-1} \mathrm{mM}^{-1}$; modified according to Tien and Kirk) (34). 


\section{Textile dye decolorization by isolated fungal strains}

The dye used in this study was Remazol Marine Blue (CI Reactive Blue 203) and its chemical structure was given in Fig. 1. The textile dye was added to the solid media at $200 \mathrm{mg} / \mathrm{l}$ of final dye concentration before autoclaving. Petri dishes with isolated fungal strains were incubated at $26^{\circ} \mathrm{C}$ for four weeks and monitored in order to detect decolorization capability.

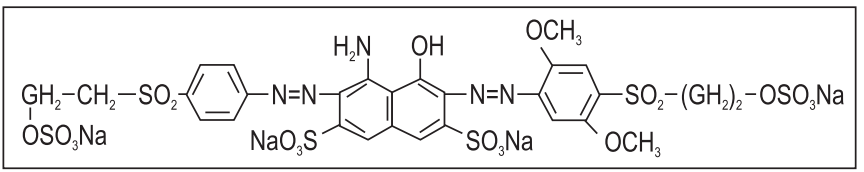

Figure 1. Chemical structure of Remazol Marine Blue (CI Reactive Blue 203)

Tetrasodium-4-amino-6-[2,5-dimethoxy-4-(2-sulfoxyethylsulfonyl) phenylazo]-5-hydroxy-3-(4-(2-(sulfoxyethylsulfonyl) phenylazo)naphtalene-2,7-disulfonate $\left(\mathrm{C}_{28} \mathrm{H}_{29} \mathrm{~N}_{5} \mathrm{O}_{21} \mathrm{~S}_{6} .4 \mathrm{Na}\right)$

\section{RESULTS AND DISCUSSION}

Screening for ligninolytic enzyme in fresh fruitbody extracts

Literature about geographical and climatic repartition of autochthonous fungal flora or describing biodiversity in a given region for ligninolytic enzymes production is scarce (9). In this study, thirty autochthonous fungal strains were harvested from Bornova-Izmir in Turkey and identified in Ege University, Faculty of Science Microbiology Section according to their macroscopic and microscopic properties. In the fresh fruitbody extracts, laccase, manganese peroxidase and lignin peroxidase activities were screened. Table 1 gives the primary screening results in detail.

The highest level of ligninolytic activities was obtained by the T.versicolor, well known ligninolytic enzyme producer, which has both Lac and MnP activities (Table 1). Although Trametes hirsuta phylogenitically closely related to the specie of T.versicolor, has quite low laccase activity compared with T.versicolor. However, it is necessary that to consider the age of mushroom, when T.hirsuta as well as A.biennis was harvested, they were highly old. We also noticed that Lyophyllum subglobisporium, Inocybe longicystis, Clitocybe sp., and Ramaria stricta, which have never been presented in the literature due to secretion of ligninolytic enzymes, have laccase and Ganoderma carnosum, Lepista nuda and Agrocybe sp. have manganese peroxidase activities. However, while Coprinus atramentarius showed high manganese peroxidase activity, Coprinus domesticus presented neither manganese peroxidase nor laccase acitivity. Therefore, screening of ligninolytic enzymes in the fresh fruit body extracts can be a quick screening method and it can give some ideas about further experiments.
Table 1. Screening for ligninolytic enzyme in fresh fruit body extracts.

\begin{tabular}{lcc}
\hline \multicolumn{1}{c}{ Fungal strains } & $\mathrm{MnP}(\mathrm{U} / \mathrm{L})$ & $\mathrm{Lac}(\mathrm{U} / \mathrm{L})$ \\
\hline Abortiporus biennis & 27.04 & - \\
Agaricus sp & 22.49 & 4.27 \\
Agrocybe aegerita & 19.60 & 3.463 \\
Agrocybe sp. 1 & 76.44 & 28.86 \\
Agrocybe sp. 2 & 21.61 & 1.83 \\
Clitocybe sp. & 17.4 & 163.60 \\
Coprinus atramentarius & 142.70 & 2.34 \\
Coprinus domesticus & - & - \\
C. plicatilis & 11.91 & 9.00 \\
Cortinarius sp 1 & 59.14 & 7.22 \\
Cortinarius sp 2 & 16.54 & 15.35 \\
Ganoderma carnosum & 86.19 & - \\
Inocybe lacera & 2,363 & 1,120 \\
Inocybe longicystis & 17.20 & 113.90 \\
Lactarius delicious & 34.1 & 0.36 \\
Lepiota naucina & 7.96 & - \\
Lepista nuda & 39.48 & 25.98 \\
Lepiota sp. 1 & 25.79 & 6.42 \\
Lepiota sp. 2 & 18.90 & 4.39 \\
Leptonia lazunila & 12.90 & 17.40 \\
Lyophyllum subglobisporium & 56.22 & 165.7 \\
Pleurotus ostreatus & 52.78 & 3.64 \\
Ramaria stricta & 85.61 & 87.64 \\
Rhizopogan luteus & 3.17 & - \\
Russula rosacea & 52.89 & 57.76 \\
Russula sp. & 57.89 & 26.64 \\
Suillus luteus & - & - \\
Trametes hirsuta & 31.48 & 5.61 \\
Trametes versicolor & 993.43 & 136.68 \\
Volveriella sp. & 4.90 & - \\
\hline & & \\
& &
\end{tabular}

Spores of some fungal strains such as Abortiporus biennis (Strain no: ECN 100601), Cortinarius sp. (Strain no: ECN 100602), Ganoderma carnosum (Strain no: ECN 100603), Lactarius delicious (Strain no: ECN 100604), Lepista nuda (Strain no: ECN 100605), Lyophyllum subglobisporium (Strain no: ECN 100606), Pleurotus ostreatus (Strain no: ECN 100607), Ramaria stricta (Strain no: ECN 100608) and Trametes versicolor (Strain no: ECN 100609) were isolated and pure cultures were obtained.

In order to observe the ligninolytic enzymes production by screening, $0.01 \%$ guaiacol and syringaldazine were used as an indicator for the ligninolytic enzyme rection with isolated fungal strains on 2\% MEA or PDA plates. The positive reactions were determined by a colorless halo around microbial growth. Table 2 presents a comparison of reactions of isolated fungal strains with containing synthetic indicators on appropriate agar plates. 
Table 2. Comparison of reactions of isolated fungal strains with containing synthetic indicators on appropriate agar plates.

\begin{tabular}{|c|c|c|c|}
\hline Isolated fungal strains & Strain no & Guaiacol & $\begin{array}{l}\text { Syringal- } \\
\text { dazine }\end{array}$ \\
\hline Abortiporus biennis & ECN 100601 & + & - \\
\hline Cortinarius sp 2 & ECN 100602 & \pm & - \\
\hline Ganoderma carnosum & ECN 100603 & + & - \\
\hline Lactarius delicious & ECN 100604 & - & - \\
\hline Lepista nuda & ECN 100605 & \pm & - \\
\hline $\begin{array}{l}\text { Lyophyllum } \\
\text { subglobisporium }\end{array}$ & ECN 100606 & \pm & - \\
\hline Pleurotus ostreatus & ECN 100607 & + & - \\
\hline Ramaria stricta & ECN 100608 & \pm & - \\
\hline Trametes versicolor & ECN 100609 & + & - \\
\hline
\end{tabular}

+: strong positive reaction; -: negative reaction; \pm : weak positive reaction.

As seen from the Table 2, T. versicolor, P. ostreatus, A. biennis and G. carnosum gave strong positive reactions on guaiacol without being positive on syrinaldazine whereas $L$. subglobisporium, $R$. stricta and $L$. nuda were weak positive reactions on guaiacol and no reactions with syrinaldazine due to the specificity of the indicators. Only one strain, Lactarius delicious, showed no reactions with synthetic phenolic reagents. Our results suggest that primary screening of ligninolytic enzymes in fresh fruitbody extracts and secondary screening with synthetic reagents, providing easily detection, can be used for predetermination of fungal strains which are capable of lignin-degradation.

\section{Ligninolytic enzyme production from isolated strains}

White-rot fungi require trace amounts of essential heavy metals such as manganese, molybdenum, zinc or nickel for their growth, however these metals are toxic for fungi when present in excess. It was known that extracellular ligninolytic enzymes are regulated by heavy metals on the level of transcription as well as during their action (2). In addition, lignin-modifying enzymes are secreted by white-rot fungi during their secondary metabolism (12), and the synthesis and secretion of these enzymes is often induced by limited carbon or nitrogen levels (15). Furthermore, agitation rate affects enzyme production via mass and oxygen transfer. Therefore, in this study, various culture mediums with different composition and different agitation rates were investigated for ligninolytic enzymes production.

Trametes versicolor is one of the wood-inhabiting fungi and extensively studied for ligninolytic enzymes production, although the ligninolytic mechanisms of Abortiporus biennis have been described in the recent literature. Furthermore, it was known that $\mathrm{LiP}$ is not secreted by $T$. versicolor (22). Isolated fungal strains were incubated on $2 \% \mathrm{MEA}$ at $26^{\circ} \mathrm{C}$ for 4 days and inoculated into $100 \mathrm{ml}$ malt extract broth at $26^{\circ} \mathrm{C}$ and 165 $\mathrm{rpm}$. The pellets were inoculated into $250 \mathrm{ml}$ Erlenmeyer flasks containing second medium and incubated at $26^{\circ} \mathrm{C}$. As seen from the Fig. 2 and Fig. 3, the agitation rate significantly affects Lac and $\mathrm{MnP}$ production.

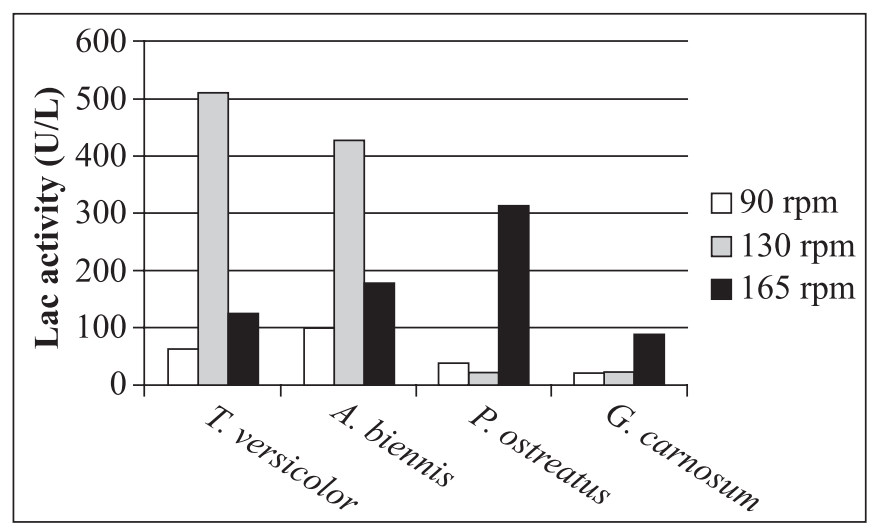

Figure 2. Effect of different agitation rates on Lac production by isolated fungal strains.

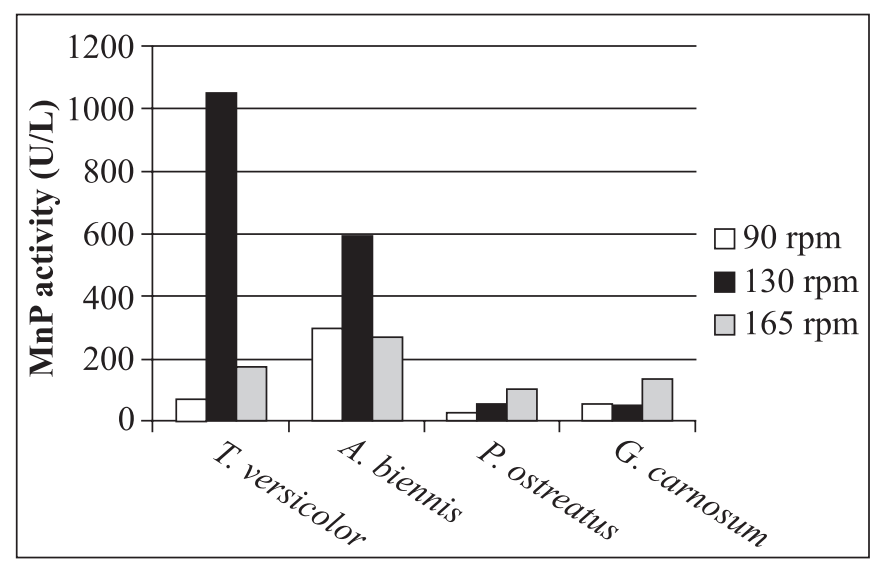

Figure 3. Effect of different agitation rates on $\mathrm{MnP}$ production by isolated fungal strains.

Fig. 4(a) presents that for T. versicolor and A. biennis the maximum Lac activities were obtained after 7 and 11 days incubation of the strains at $130 \mathrm{rpm} 511.10 \mathrm{U} / 1$ and $427.03 \mathrm{U} / \mathrm{l}$, respectively. Fig. 4(b) demonstrates that for A. biennis and $T$. versicolor the maximum $\mathrm{MnP}$ activities were obtained after 4 and 6 days incubation of the strains at $130 \mathrm{rpm} 597.50 \mathrm{U} / 1$ and 
Erden, E. et al.

1051.17 U/l, respectively. Contrary to results of Jaszek et al. (14), they have reported that in $T$. versicolor culture medium Lac activity were detected approximately $100 \mathrm{nkat} / \mathrm{mg}$ protein and $\mathrm{MnP}$ activity were detected $120 \mathrm{nkat} / \mathrm{mg}$ protein whereas in A. biennis cultures $3.66 \mathrm{nkat} / \mathrm{mg}$ protein MnP activity and 25 nkat/mg protein Lac activity were detected.

The white-rot fungi Pleurotus ostreatus is a cultivated edible mushroom and it is a saprotroph that acts as a primary decomposer on wood. P. ostreatus produces several ligninolytic enzymes such as laccase, manganese peroxidase that catalyse one-electron oxidation of lignin units, but not $\mathrm{LiP}$ (11). Isolated fungal strain was activated on $2 \% \mathrm{MEA}$ at $26^{\circ} \mathrm{C}$ for 7 days and inoculated into $100 \mathrm{ml}$ malt extract broth in $250 \mathrm{ml}$ Erlenmeyer flasks at $26^{\circ} \mathrm{C}$ and $165 \mathrm{rpm}$. The pellets were inoculated into 250 $\mathrm{ml}$ Erlenmeyer flasks containing second medium and incubated at $26^{\circ} \mathrm{C}$. Fig. 2 and Fig. 3 show the effects of agitation rate on Lac and MnP production. As seen from the Fig. 5(a) and Fig. 5(b), the highest MnP and Lac activities were obtained after 10 days incubation of the strain at $165 \mathrm{rpm} 101.81 \mathrm{U} / \mathrm{l}$ and $311.55 \mathrm{U} /$ 1, respectively. However, contrary to results Stajic et al. (32), for different $P$. ostreatus strains revealed Lac activities varying a range from 3.2 to $256 \mathrm{U} / \mathrm{l}$ in submerged fermentation of mandarin peels.

Ganoderma carnosum belongs to subclass of white-rot basidiomycetes. Ganoderma genus has been widely studied since some of its species have medicinal properties. G. lucidum has been used for promotion of vitality and longevity (20) and prevention and treatment of various human diseases in China

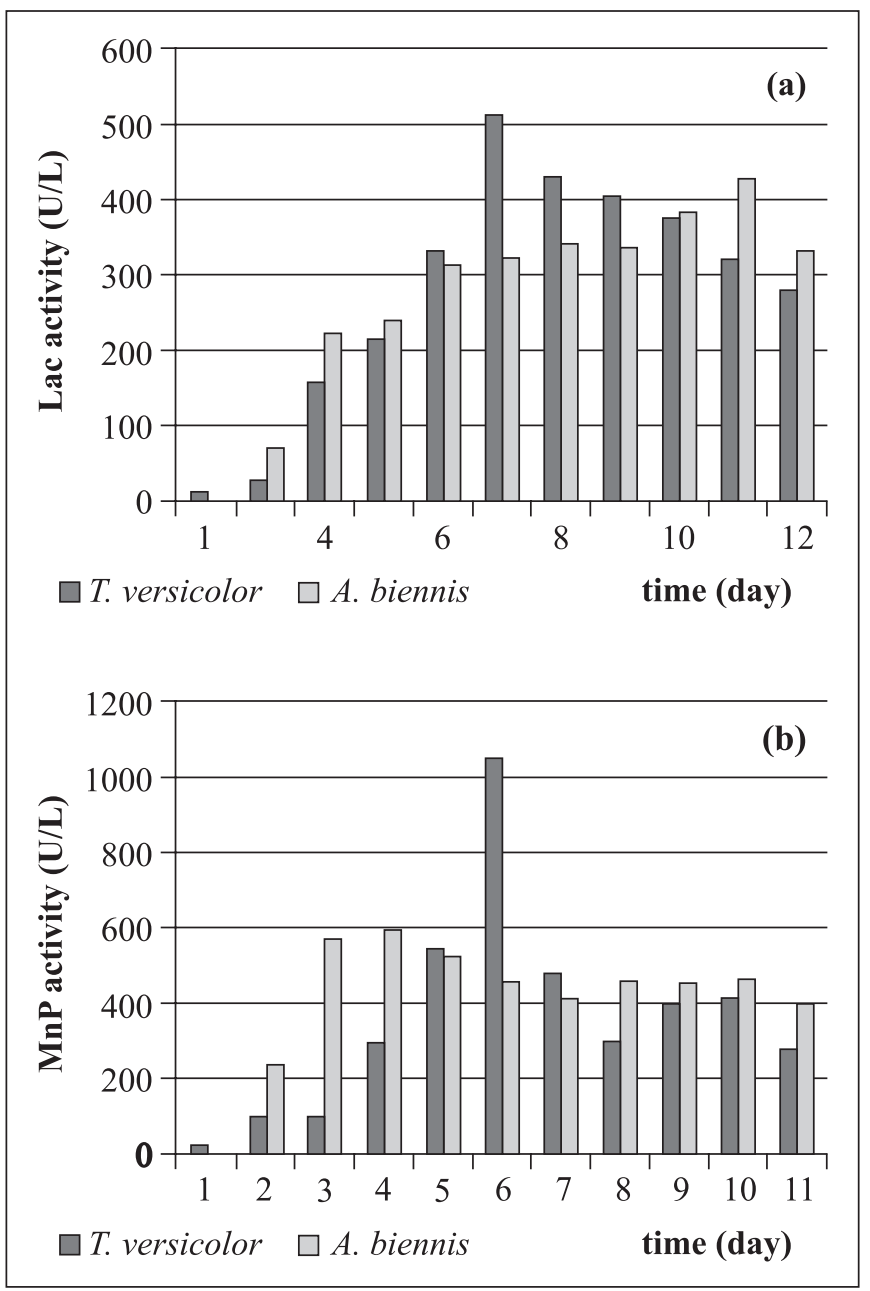

Figure 4(a). Lac production of T. versicolor and A. biennis at $26^{\circ} \mathrm{C}$ and $130 \mathrm{rpm}$;

Figure 4(b). MnP production of T. versicolor and A. biennis at $26^{\circ} \mathrm{C}$ and $130 \mathrm{rpm}$.

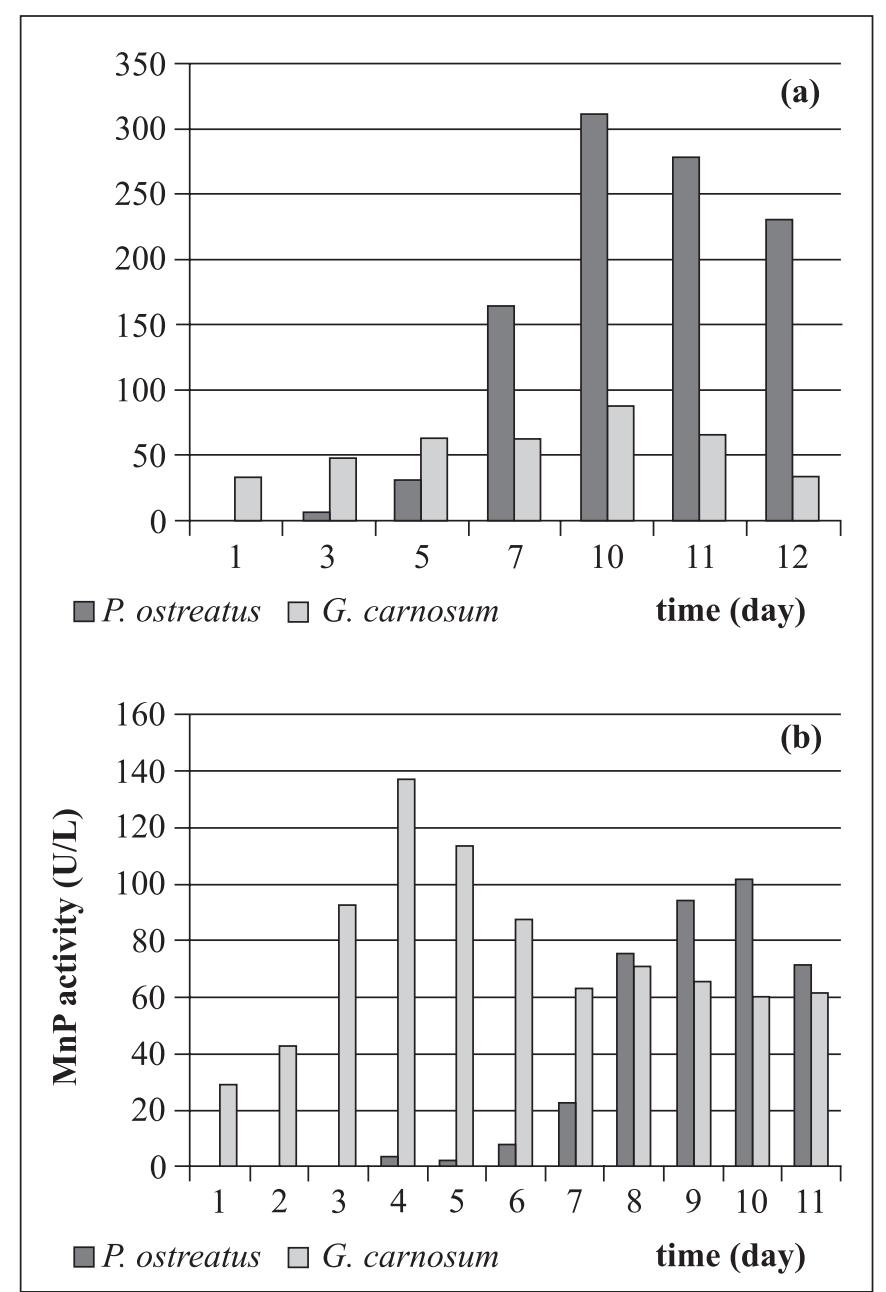

Figure 5(a). Lac production of P. ostreatus and G. carnosum at $26^{\circ} \mathrm{C}$ and $165 \mathrm{rpm}$.

Figure 5(b). MnP production of P. ostreatus and G. carnosum at $26^{\circ} \mathrm{C}$ and $165 \mathrm{rpm}$. 
and other Asian countries (19,30). Additionally, these fungi have also raised interest in the area of plant pathology. One of the important aspects of Ganoderma species associated with the use of its ligninolytic potential, but the studies about this fungus are not completely known (8). Ganoderma carnosum, isolated in this study, was activated on $2 \%$ MEA at $26^{\circ} \mathrm{C}$ for 7 days and inoculated into $100 \mathrm{ml}$ malt extract broth in $250 \mathrm{ml}$ Erlenmeyer flasks at $26^{\circ} \mathrm{C}$ and $165 \mathrm{rpm}$. The pellets were transferred to 250 $\mathrm{ml}$ Erlenmeyer flasks containing third medium and incubated at $26^{\circ} \mathrm{C}$. As seen from the Fig. 2 and Fig. 3, agitation rates influenced Lac and MnP production and the Fig. 5(a) and Fig. 5(b) demonstrate that the maximum $\mathrm{MnP}$ and Lac activities were obtained after 4 and 10 days incubation of the strain at $165 \mathrm{rpm}$ $136.99 \mathrm{U} / \mathrm{l}$ and $87.92 \mathrm{U} / \mathrm{l}$, respectively, but LiP activity was not detected. In a few literatures, Ganoderma sp. strains have been reported to produce ligninolytic enzymes by using of several agricultural wastes and food industry wastes in submerged fermentation. As the results were compared, Lac activities varying a range from 0.04 to $97000 \mathrm{U} / \mathrm{l}$ and $\mathrm{MnP}$ activities varying a range from 0.02 to $135 \mathrm{U} / 1$ were observed due to types of wastes $(8,31)$.

Lyophyllum subglobisporium, Ramaria stricta and Lepista nuda were incubated on PDA slants and Lactarius delicious was incubated on MEA slants at $26^{\circ} \mathrm{C}$ for 7 days. After incubation they were inoculated into $100 \mathrm{ml}$ potato dextrose broth and $100 \mathrm{ml}$ malt extract broth in $250 \mathrm{ml}$ Erlenmeyer flasks at $26^{\circ} \mathrm{C}$ and $165 \mathrm{rpm}$. After the growth period pellets were inoculated $250 \mathrm{ml}$ Erlenmeyer flasks containing medium and incubated at $26^{\circ} \mathrm{C}$ and $165 \mathrm{rpm}$. However, significant ligninolytic enzyme activities were not detected in submerged culture conditions for 30 days whereas found out in fresh fruit body extracts of R.stricta. L. subglobisporium and L. nuda cannot be cultivated under these cultivation conditions. There is not any literature for these Basidiomycetes producing ligninolytic enzymes. Therefore, further experiments are required for using these fungi in industrial and biotechnological process.

This study provides that fresh fruit bodies of fungus can be used for the screening of new and alternative enzymes as a primary method, especially for the production of ligninolytic enzymes and confidence of this method was confirmed by guaiacol tests as a secondary method.

\section{Applications of isolated fungal strains for textile dye decolorization}

White-rot fungi are capable of decolorization of some textile dyes via producing ligninolytic enzymes. In this study, isolated fungal strains were used for decolorization of a textile dye, Remazol Marine Blue, on agar plates. As seen from the Fig. 6,

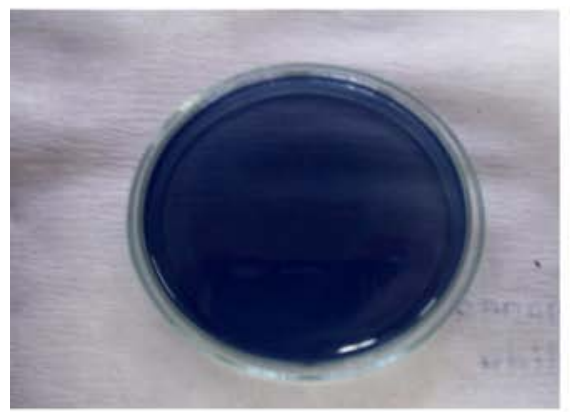

(a) Blank

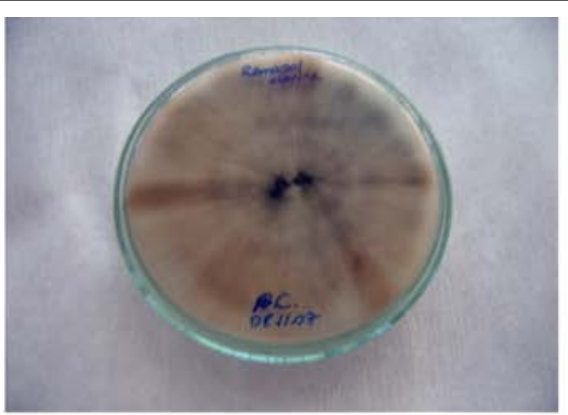

(b) G. carnosum ECN 100603

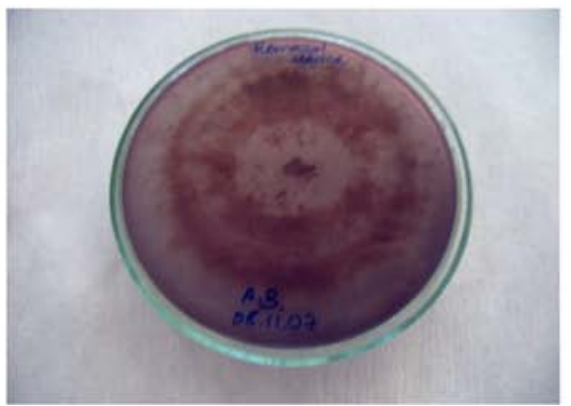

(d) A.. biennis ECN 100601

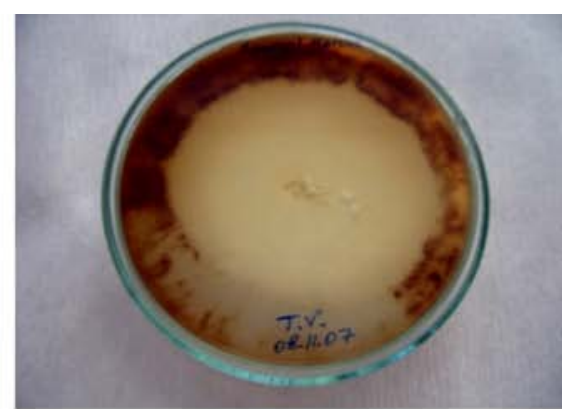

(c) T. vercicolor ECN 100609

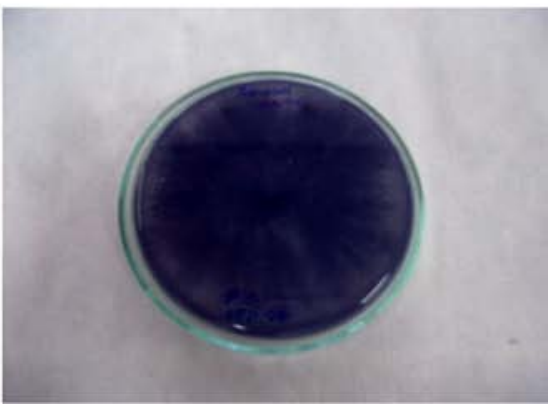

(e) P. ostreatus ECN 100607

Figure 6. Decolorization of Remazol Marine Blue on agar plates. (a) Blank; (b) G. carnosum ECN 100603; (c) T. versicolor ECN 100609; (d) A. biennis ECN 100601; (e) P. ostreatus ECN 100607. 
decolorization of Remazol Marine Blue was observed effectively on agar plates with G. carnosum ECN 1400603 strain and T. versicolor ECN 100609 strain for two weeks while P. ostreatus ECN 100607 was not efficient to decolarize the dye for four weeks. On agar plate with A. biennis ECN 100601, it was detected that there was a transformation of dye.

\section{RESUMO}

\section{Triagem de enzimas ligninolíticas de fungos autóctones e aplicações para descoloramento de Remazole Marine Blue}

Este estudo apresenta novas cepas de fungos produtores de enzimas ligninolíticas com potencial de aplicação em processos industriais e biotecnológicos. Trinta cepas de fungos autóctones foram obtidos em Bornova-Izmir, Turquia. Os extratos frescos dos corpos de frutificação foram submetidos à triagem de atividade de lacase, manganês peroxidase e lignina peroxidase, que são as principais enzimas de degradação de ligninocelulose pelos Basidiomycetes. Foram isolados esporos de Cortinarius sp, Tramnetes versicolor, Pleorotus ostreatus, Abortiporus biennis, Lyophyllum subglobisporium, Ramaria stricta, Ganoderma carnosum, Lactarius delicius ve Lepista desnuda, investigando-se as condições ótimas de cultivo em fermentação submersa para produção de enzimas ligninolíticas com elevado rendimento. Além disso, as cepas fúngicas isoladas foram monitoradas em placas de ágar quanto a capacidade de descoloramento do corante têxtil Remazole Marine Blue.

Palavras-chave: Basidiomycetes, enzimas ligninolíticas, descoloramento

\section{REFERENCES}

1. Archibald, F.S.; Bourbonnais, R. (1997). Kraft pulp bleaching and delignication by Trametes versicolor. J. Biotechnol. 53, 215-236.

2. Baldrian, P. (2003). Interactions of heavy metals with white-rot fungi. Enzyme Microb. Technol. 32, 78-91.

3. Bao, W.; Fukushima, Y.; Jensen, K.A.; Moen, M.A.; Hammel, K.E. (1994). Oxidative degradation of non-phenolic lignin during lipid peroxidation by fungal manganese peroxidase. FEBS Lett. 354, 297300.

4. Bourbannais, R.; Paice, M.G. (1988). Veratryl alcohol oxidases from the lignin degrading basidiomycete Pleurotus sajor-caju. Biochem J. $255,445-50$.

5. Couto, S.R.; Toca-Herra, J.L. (2007). Laccase production at reactor scale by filamentous fungi. Biotechnol. Adv., 25, 558-569.

6. Couto, S.R.; Herrera, J.L. (2006). Industrial and biotechnological applications of laccases. Biotechnol. Adv. 24, 500-513.

7. De Jong, E.; De Vries, F.P.; Field, J.A.; Van Der Zwan, R.P.; De Bont, J.A.M. (1992). Isolation and screening basidiomycetes with high peroxidative activity. Mycol. Res. 12, 1098-1104.

8. De Souza Silva, C.M.M.; De Melo, I.S.; De Oliveira, P.R. (2005). Ligninolytic enzyme production by Ganoderma spp. Enzyme Microb. Technol. 37, 324-329.
9. Dhouib, A.; Hamza, M.; Zouari1, H.; Mechichi, T.; Hmidi, R.; Labat, M.; Martinez, J.M.; Sayadi, S. (2005). Screening for ligninolytic enzyme production by diverse fungi from Tunisia. World J. Microbiol. Biotechnol., 21, 1415-1423.

10. Eriksson, K.E.L.; Blanchette, R.A.; Ander P. (1990). Microbial and enzymatic degradation of wood and wood components. Berlin: Springer-Verlag.

11. Giardina, P.; Palmieri, G.; Fontanella, B., Rivieccio, V.; Sannia, G. (2000). Manganese peroxidase isoenzymes produced by Pleurotus ostreatus grown on wood sawdust. Arch. Biochem. Biophys. 376 (1), 171-179.

12. Hammel, K.E. (1997). Fungal degradation of lignin. In G. Cadish, \& KE Giller (eds), Driven ByNature: Plant Litter Quality and Decomposition. CAB International, UK, p. 33-45.

13. Hatakka A. (1994). Lignin-modifying enzymes from selected whiterot fungi: production and role in lignin degradation, FEMS Microbiol. Rev. 13, 125-135.

14. Jaszek, M.; Grzywnowicz, K.; Malarczyk, E.; Leonowicz, A. (2006). Enhanced extracellular laccase activity as a part of the response system of white rot fungi: Trametes versicolor and Abortiporus biennis to paraquat-caused oxidative stress conditions. Pestic. Biochem. Physiol. 85, 147-154.

15. Keyser, P.; Kirk, T.K.; Zeikus, J.G. (1978). Ligninolytic enzyme system of Phanerochaete Chrysosporium: sythensized in the absence of lignin in response to nitrogen starvation. J. Bacteriol. 135, 790797.

16. Kiiskinen, L.L.; Rattö, M.; Kruus, K. (2004). Screeing for novel laccase-producing microbes. J. Appl. Microbiol. 97, 640-646.

17. Kirk, T.K.; Farrell, R.L. (1987). Enzymatic combustion: the microbial degradation of lignin. Annu. Rev. Microbiol. 41, 465-505.

18. Kuwahara, M.; Glenn, L.K.; Morgan, M.A.; Gold, M.H. (1984). Separation and characterization of two extracellular $\mathrm{H}_{2} \mathrm{O}_{2}$-dependent peroxidases from ligninolytic cultures of Phanerochaete chrysosporium. FEBS Lett. 169, 247-250.

19. Lin Z.B. (2001). Pharmacological functions of Ganoderma lucidum. Modern Research of Ganoderma lucidum, Beijing Medical University Press, Beijing.

20. Lu Q.Y.; Jin Y.S.; Zhang Q.; Zhang Z.; Heber D.; Go V.L.W. (2004). Ganoderma lucidum extracts inhibit growth and induce actin polymerization in bladder cancer cells in vitro, Cancer Lett. 216, 9-20.

21. Minussi, R.C.; Pastore, G.M.; Duran, N. (2002). Potential applications of laccase in the food ýndustry. Trends Food Sci. Technol. 13, 205-216.

22. Moredo, N.; Lorenzo, M.; Domínguez, A.; Moldes, D.; Cameselle, C.; Sanromán, A. (2003). Enhanced ligninolytic enzyme production and degrading capability of Phanerochaete chrysosporium and Trametes versicolor. World J. Microbiol. Biotechnol. 19, 665-669.

23. Nilsson, I.; Möller, A.; Mattiassoon, B.; Rubindamayugi, M.S.T.; Welander, U. (2006). Decolorization of synthetic and real textile wastewater by the use of white rot fungi. Enzyme Microb. Technol. 38: $94-100$

24. Nishida, T.; Yoshiri. K.; Mimura, A.; Takahara, Y. (1988). Lignin biodegradation by wood-rotting fungi I. Screening of lignin degrading fungi. Mokuzai Gakkaishi. 34, 530-536.

25. Piontek, K.; Smith, A.T.; Blodig, W. (2001). Lignin peroxidase structure and function. Biochem. Soc. Trans. 29(Pt 2), 111-6.

26. Pointing, S.B. (2001). Feasibility of bioremediation by white-rot fungi. Appl. Microbiol. Biotechnol. 57, 20-33.

27. Revin, V.; Kadimaliev, D.A.; Shutova, V.V.; Samuilov, V.D. (2002). Wood Lignin Modification by the Fungus Panus tigrinus. Appl. Biochem. Microbiol. 38 (5), 450-453.

28. Saparrat, M.C.N.; Martinez, M.J.; Cabello, M.N.; Arambarri, A.M. (2002). Screening for ligninolytic enzymes in autochthonus fungal strains from Argentina isolated from different substrata. Rev. Iberoam. Micol. 19, 181-185. 
29. Schoemaker, H.E. (1990). On the chemistry of lignin degradation. Recueil des Travaux Chimiques des Pays-Bas. 109, 255-272.

30. Shiao, M.S. (2003). Natural products of the medicinal fungus Ganoderma lucidum: Occurrence, biological activities, and pharmacological functions, Chem. Rec. 3, 172-180.

31. Songulashvili, G.; Elisashvili, V.; Wasser, S.P.; Nevo, E.; Hadar, Y. (2007). Basidiomycetes laccase and manganese peroxidase activity in submerged fermentation of food industry wastes. Enzyme Microb. Technol. 41, 57-61.

32. Staji'c, M.; Persky, L.; Friesem, D.; Hadar, Y.; Wasser, S.P.; Nevo, E.; Vukojevi', J. (2006). Effect of different carbon and nitrogen sources on laccase and peroxidases production by selected Pleurotus species. Enzyme Microb. Technol. 38, 65-73.
33. Thurston, C. (1994). The structure and function of fungal laccase Microbiology 140, 19-26.

34. Tien, M.; Kirk, K.T. (1984). Lignin Peroxidase of Phanerochaete chrysosporium. Methods Enzymol. 161, 238-49.

35. Winquist, E.; Moilanen, U.; Mettälä, A.; Leisola, M.; Hatakka, A. (2008). Production of lignin modifying enzymes on industrial waste material by solid-state cultivation of fungi. Biochem. Eng. J., 42 (2), 128-132.

36. Zhao, X.; Hardin, I.R. (2007). HPLC and spectrophotometric analysis of biodegradation of azo dyes by Pleurotus ostreatus. Dyes and Pigmets. 73, 322-325. 